\title{
CORRESPONDENCE.
}

Brotis Vulneraria Again.

One of the many fine things secured by Mr. Bice at electric light during the season of 1896 was a specimen of that perplexing aberrant Lepidopteron, Brotis vulneraria, Hub.

In the Canadian Entomotogist for 1886 , Vol. XVIII., page 72, Mr. $\mathrm{Ph}$. Fischer reports the capture of a specime.ı in Buffalo at electric light and gives some description of it and an account of the difficulty experienced by the various authors to decide its position in systematic classification. At page 136 the Rev. G. D. Hulst comments on that report and gives further information upon the subject, and quotes Walker as saying that "it does not seem to fit well anyw'here."

Mr. Fischer identified his specimen by Hubner's figure. I had no difficulty in recognizing the London specimen by Guence's illustration of it in his Lepidopteres Phalenites, plate 22, fig. 9, under the generic name Sphacelodes, but was indebted to Dr. J. B. Smith for a clue to its location in his List of 1891 . I had forgotten these notices, where Dr. Hulst gives its generic synonymy, and the cause of it, although I read them with interest mingled with curiosity at the time, knowing nothing whatever of the moth referred to.

It is an interestingly anomalous insect. Whether in a tropical collection it has fitting associates with which it may harmonize and bear a resemblance, it certainly stands out conspicuously distinct in the Ontario one to which Mr. Bice has kindly donated it. J. Alston Mofrat.

\section{Podisus Placidus.}

In the May number of this journal Mr. Kirkland, of the Gypsy Moth Committee, publishes the descriptions of two Pentatomids by Mr. UhlerPodisus placidus and Euschistus politus.. Of Podisus placidus he says he was unable to find the original description, nor could Prof. Uhler at the time give him the reference. This description may be found in the American Entumologist, Vol. II., page 203.

E. P. VAN DUzeE.

Buffalo, N. Y.

Erratum.-On page 10t, seventh line from bottom, for Dorylide read MYrmicide.

Mailed June 4th, 1897. 